\title{
THE GENDERED RHETORIC OF COLONIALISM AND ANTI-COLONIALISM IN TWENTIETH- CENTURY INDONESIA
}

\author{
Frances Gouda
}

In the Anti-Revolutionary Party's political platform of 1879, Ons Program, Dr. Abraham Kuyper-the pater familias of the orthodox Dutch Reformed political forces in the Netherlands-inaugurated a discourse about colonial policy which proposed that henceforth the Dutch as colonial masters in Indonesia should perform the role of faithful tutors to indigenous pupils. They ought to serve as generous guardians, Kuyper sermonized, dedicated to the instruction and edification of their native "children." While God had forged the bonds between the Netherlands and the Indies, Ons Program held forth-and the policy of the Anti-Revolutionary Party should be to maintain that which God had ordained-the Dutch East India Company (VOC) and the gruesome exploitation of the Cultivation System (cultuurstelsel) had committed a cardinal sin by violating His commandment that "Thou shalt not steal." Now it was incumbent upon the Dutch in Southeast Asia to begin the delicate task of replacing these "greedy tendencies" with a policy of moral obligation and the "uplifting" of Indonesians. In the Anti-Revolutionary Party's political lexicon, ethical colonial governance inspired by Christian faith implied both selfless dedication and stern instruction on the part of those who wished to execute God's will on earth. ${ }^{1}$ In short, in the period between the formulation of Ons Program in 1879 and World War II the terms ethical trusteeship, moral tutelage, and parental guidance were inextricably linked to any and all discussions about Dutch colonial policy in Indonesia.

Research for this article was supported, in part, by a Grant-In-Aid from the American Council of Learned Societies and a Fellowship from the Woodrow Wilson International Center for Scholars. An abbreviated version was presented to the inter-university colloquium on "Rhetoric and Disciplinary Inquiry," George Washington University, November 1992. I would like to thank Jennifer Lindsay, Elsbeth Locher-Scholten, and Takashi Shiraishi for their extremely helpful suggestions and comments.

1 Elsbeth Locher-Scholten, Ethiek in fragmenten. Vijf studies over koloniaal denken en doen van Nederlanders in de Indonesische Archipel, 1877-1942 (Utrecht: HES Publishers, 1981), pp. 182-84; Hendrik Colijn, Hoofdlijnen onzer koloniale politiek (The Hague: Calvinistische Juristen Vereeniging, June 8, 1932), pp. 33-34, and C. Snouck Hurgronje, Colijn over Indie (Amsterdam: H.J.W. Becht, 1928), pp. 2-3. 
Almost forty years later, on November 14, 1918, during the second session of the newly created Volksraad (People's Council), one of its Indonesian members, Tjipto Mangoenkoesoemo, boldly criticized the Indies government, and in doing so he exhibited his wizardry with the Dutch language by displaying a mischievous sense of humor. Tjipto also parodied the gendered nature of the parental metaphors of colonial rule in order to illustrate his objections to Dutch policies in the Indies. After all, a wide range of complementary if paradoxical tropes about strict parental instruction and the compassionate nurturance of indigenous children saturated the "ethical" rhetoric of Dutch colonial legitimacy that had been initiated in the late nineteenth century.

The Dutch were not unique in this regard. The idiom of parental obligation or the vocabulary of family ties, in fact, were an essential, constitutive metaphor of all colonial discourses, regardless of their national context. ${ }^{2}$ Whenever Europeans asserted the validity of colonial rule, in Southeast Asia or elsewhere, they almost always appealed to their parental duties toward their native progeny. Whether articulated in Dutch, French, or English, discourses designed to vindicate colonial regimes alluded to an occasional maternal model of empathetic caring for the welfare of indigenous peoples, on the one hand, and a paternalistic equivalent of rigorous training of throngs of native children, on the other. This language, it seemed, was designed to represent colonial societies as a great happy family composed of benevolent if stern white-skinned parents who guided their brown-skinned offspring to basic literacy and psychological maturity. In general, Europeans' invocation of family imagery, across the board, was intended to bolster the myth of colonial societies as a natural, organic whole, and parental symbolism constituted a root metaphor that framed, defined, and delineated the discursive practices of colonial mastery. ${ }^{3}$

Tjipto Mangoenkoesoemo, for his part, employed the same constitutive metaphor, but he intentionally turned it upside down or inside out in order to subvert the colonial rhetoric of legitimacy. Addressing the Volksraad in 1918, Tjipto declared that, despite the government's stated intention to labor with all its might on behalf of the welfare of the Indonesian people-a pledge Governor General van Limburg Stirum had solemnly repeated at the ceremonial occasion of the opening of the Volksraad, earlier in the year-he could not fail to notice a major weakness of character. In Tjipto's anthropomorphized vision of the Indies colonial state, the government resembled a capricious schoolmaster incapable of keeping his promises. The incorrigible Tjipto reminded his audience, however, that Christians always say that "the heavens exult more in the conversion of one sinner than they rejoice in a multitude of compliant believers," and he hoped that the government might seek solace in this Christian injunction. ${ }^{4}$

\footnotetext{
2 As Lynn Hunt has recently argued in The Family Romance of the French Revolution (Berkeley: University of California Press, 1992), narratives about the family are central to the constitution of "all forms of authority." The family romance, she notes, functions as a primordial category for organizing "any kind of political experience." Pp. 8, 196.

${ }^{3}$ For a discussion of the use of pedagogical, heuristic, and constitutive metaphors in economics, see Arjo Klamer and Thomas C. Leonard, "So What's an Economic Metaphor?" Paper presented at George Washington University, September 1992. See also: Arjo Klamer, "Towards the Native's Point of View: The Difficulty of Changing the Conversation," in Economics and Hermaneutics, ed. Don Lavoie (New York: Routledge, 1990), and Philip Mirowski, More Heat than Light (New York: Cambridge University Press, 1989).

4 Handelingen van de Volksraad, 1918 (Batavia: Landsdrukkerij, 1918), Tweede gewone zitting, Aanvullingsbegroting voor het dienstjaar 1919, Algemeene Beschouwingen, 9e Vergadering, 14 November, 1918, p. 159. For a description of Tjipto as "incorrigible," see Takashi Shiraishi, An Age in Motion. Popular Radicalism in Java, 19121926 (Ithaca: Cornell University Press, 1990), pp. 120-27.
} 
Tijpto was far from convinced, however, that this would be the case, and he registered his opinion with scathing wit. Having established the Volksraad, he intoned, "the government received so many feathers in her cap that in my imagination she acquired the appearance of an [American] Indian with a feather headdress." He then switched genders to decribe the ominous impact of this plumed headgear, as if it were a tangible implement of power and the colonial state could only be masculine when it adopted an aggressive posture. These feathers, he said, were contrived "to endow him with such a belligerent look that the enemy might flee in confusion." 5

In his criticism of the Dutch colonial state, Tjipto's transition from feminine to masculine imagery must have been a deliberate strategy, since the Dutch word for government (regering) is a female noun; his sudden reference to the government as a masculine entity most likely was a calculated maneuver. After all, in addition to parental metaphors, gendered tropes have also been used throughout history to illustrate discrepancies of power. Gendered figures of speech signify all sorts of unequal social relationships that are not intrinsically connected to sexual difference per se but constitute, instead, graphic symbolsuniversally recognizable-invoked to underscore relations of command and subordination. ${ }^{6}$ Through the use of metaphor, Joan Wallach Scott and other post-structuralists have reminded us in recent years, gendered discourses are dislodged from the realm of sex roles, emerging as symbolic and narrative tools designed to illuminate differential power positions in general; as such they become essential elements of almost every aspect of social organization or political structure. ${ }^{7}$ Thus Tjipto's shift from a feminine to a masculine government-facilitated, of course, by certain peculiarities of the Dutch language-was a rhetorical trick he pulled out of his orator's hat to expose the contradictory character of Dutch colonial policies in Indonesia.

Tjipto applied his discursive tactics more transparently when he continued his address to the Volksraad. He joked irreverently about the government's Ethical Policy which, he said, is portrayed as Juffrouw Ethica (Miss Ethics), who reputedly "is gentle and warm-hearted and has beautiful eyes, a classic nose, and such a delectable mouth that the lonely voices which register their indifference to Juffrouw Ethica's beauty are dismissed as people with vulgar taste, who thereby forfeit their right to participate in the discussion." When these dissonant voices, Tjipto continued, wonder publicly whether the sugary sweet and elaborately made up "Miss Ethics, whose real face is hidden beneath a thick layer of powder" is not, in fact, an "old hag," they are silenced by the Dutch-language press. ${ }^{8}$

Tjipto's sarcasm knew no bounds. In the same speech he raised several other questions that both exposed and epitomized the government's bad faith. About recent events in Kediri in East Java, where desperately hungry Javanese men had plundered cassava from a European plantation, he ridiculed the government's saber-rattling as a shameful display of military power in the face of vulnerable and starving peasants. ${ }^{9}$ He sneered at the recent appointment of a new director of the Department of Agriculture, Industry and Trade, a man, he said, who is a greedy and impenitent colonialist, a "thoroughbred sugar baron for

\footnotetext{
5 Handelingen van de Volksraad, 1918, p. 159.

${ }^{6}$ Joan Wallach Scott, Gender and the Politics of History (New York: Columbia University Press, 1988), passim.

7 Ibid., p. 6. See also William H. Sewell's review of Gender and the Politics of History in History and Theory 29, 1 (1990): 71-82, and Doris Y. Kadish, Politicizing Gender. Narrative Strategies in the Aftermath of the French Revolution (New Brunswick: Rutgers University Press, 1991).

8 Handelingen van de Volksraad, 1918, p. 159.

9 Ibid., p. 165.
} 
whom inlanders only have value as a raw labor force enlisted to cultivate nothing but dividends for shareholders in Holland."10 He also called Dutch civil servants in the Bandung region to task for terrorizing Sundanese people in Majalaja, who had shown the courage to join Sarekat Islam. For fabricating the story that the Sundanese had elevated Tjokroaminoto, chairman of the central Sarekat Islam and also a representative to the Volksraad, to the position of raja, Tjipto accused Dutch administrators of having concocted a fairy tale so foreboding that "it might send a young lady to bed, shivering with fright, even if it is a fairy tale that thoughtful men can't take seriously."11

In his conclusion, Tjipto returned to Juffrouw Ethica; all these developments, he said, are internally related and seem to indicate that the government is afraid that Miss Ethics has "overstimulated us inlanders by casting too many amorous glances in our direction." Apparently the government thinks that now the time has come to reintroduce to center stage Miss Ethics' older sister, "the virago, the witch" (de feeks, de heks), whose name is Ancien Regime: "this old young lady with her wrinkled face, who in the past has catered so well to the needs of the Dutch East India Company, now must tuck us into bed and temper our ardent declarations of love for greater human rights and delay our march towards a happier future." 12

With sardonic humor Tjipto Mangoenkoesoemo employed masculine and feminine images to exhibit the harshness and hypocrisy of Dutch colonial policies and to register his opposition. When he emphasized the government's abuse of its superior power, he invoked the imagery of a muscular bully or a ferocious American Indian with a feather headdress engaged in typically masculine and bellicose behavior. By portraying the Indies government's ethical welfare policy on behalf of the native population as either a tired old hag or a sultry woman of dubious morals, intent on seducing Indonesians in order to render them pliable, Tjipto mocked the ways in which the Dutch colonial regime justified its rule as altruistic or charitable.

The ethical policy, after all, was based on a "moral obligation," publicly acknowledged by young Queen Wilhelmina at the turn of the century, which henceforth would inspire the government to pay back its "debt of honor" to Indonesians by nurturing their material and psychological well-being. Tjipto's depiction of Juffrouw Ethica, however, conjured up a voluptuous lady not in the least concerned with preserving her honor by fostering with motherly care the contentment and prosperity of her progeny. Instead, she was portrayed as a shameless hussy, whose "ruddy cheeks," resembling Thomas Mann's sanatorium patients in The Magic Mountain, "hid insidious symptoms beneath," while her superficial charm concealed the fact that she may have been a crumpled old woman.

Accordingly, in this essay I want to explore not only the maternal and paternal imagery that infused the rhetoric of colonial rulers intent on legitimating their position of authority over the colonial "other," but also the ways in which anticolonial critics invoked the same gendered metaphors in order to subvert the legitimacy of European mastery. "You've done very wrong, but I am still your father and mother," English military officers might say to their native subalterns during the British Raj in India, while officials representing the Indian Civil Service were known as $\mathrm{Ma}$-Bap, mother-father, to the residents of their districts. ${ }^{13} \mathrm{Ma}$ -

\footnotetext{
10 lbid., p. 160. The new director's name was Siebenga Muller.

11 Ibid., p. 163.

12 Ibid., p. 165.

13 Paul Scott, The Day of the Scorpion, Book 2 of The Raj Quartet (New York: Avon Books, 1979), pp. 403, 410, and Barbara N. Ramusack, "Cultural Missionaries, Maternal Imperialists, Feminist Allies. British Women Activists in
} 
Bap: I am your father and your mother, a phrase that quaintly conveyed the parental metaphors of colonial rule, as if colonial governance were an androgynous entity which endowed its practitioners with a flexible sexual identity and permitted them to define their task as representing either the "fatherland" or the "mother country" as they saw fit.

Bound by a straightforward patrilineal vocabulary, indigenous retainers in Indonesia, meanwhile, called local Dutch civil servants their Father, whereas they referred to the governor-general as Grandfather. ${ }^{14}$ Most Indonesians with a formal role in the colonial administration were fully aware, however, that a female Queen in a distant country required the greatest deference of all. The recognition that in the overall hierarchy of authority a female monarch rather than a male governor-general was the ultimate source of power, may have added a similar ambiguity to Indonesian perceptions of power and its gendered nature. On the whole, the Ma-Bap imagery, or the fact that sophisticated and refined Javanese priyayi were expected to call Dutch administrators their father, captured the ways in which colonial rulers employed a gendered and parental vocabulary to describe the world in which they operated, either to foster progress or to legitimize the status quo.

Parental metaphors, moreover, appealed implicitly to a series of presumptions about motherhood and fatherhood and to the particular manner in which men and women wielded control over their brood of children. On the one hand, parental symbols established a taxonomy of authority, tutelage, and obedience; they served as universally recognizable emblems of the differential positions of power of old and young-or, in a colonial setting, of knowledgeable adults from Europe and ignorant native children. On the other hand, parental discourses tacitly distinguished between a maternal and paternal style and the unique ways in which men and women used their superior status as progenitors, who always functioned, regardless of the cultural context, as the ultimate source of love and sustenance but above all, of Bildung and judgment. Parental figures of speech were thus inherently gendered in nature, since they identified the positive and sensitive qualities of parenting with motherhood, whereas they associated the need to mold and shape children into responsible and independent adults with fatherhood.

"As colonial fathers," wrote the Dutchman J.J.B. Ostmeier in the bi-weekly magazine of the blijver association "Insulinde" in 1911, for instance, we must acknowledge that our children need our guidance, "because as soon as we ease the gentle pressures imposed upon our big child it will inevitably stumble over the obstacles every human being encounters in the course of life."15 No one can blame us for treating the kleine Javaan (the small Javanese) as a big child, and the education of every child, he pontificated, requires clemency and indulgence, although on occasion it is necessary to be severe. No positive development will occur if we, as fathers, are only weak and tolerant because it is too difficult "to determine the appropriate boundary between severity and leniency." However, Ostmeier conceded, as colonial fathers we sometimes do not heed "the golden lessons of maternal experience" (moeder ondervinding), and this failure to learn from motherly intuition is the reason why we

India, 1865-1945," in Western Women and Imperialism. Complicity and Resistence, ed. Nupur Chaudhuri and Margaret Strobel (Bloomington: Indiana University Press, 1992), p. 133.

14 M. B. van der Jagt, Memoires van M.B. van der Jagt. Oud Gouverneur van Soerakarta (The Hague: H. P. Leopold, 1955), p. 299.

15 J.J.B. Ostmeier, Punten en Problemen, "Eene proeve van studie over het Javaanse volkskarakter," No. VI, Insulinde 2, 22 (November 16, 1911): pp. 3-5. 
sometimes "implement well-intentioned but awkward measures which produce nothing but adverse results." 16

Whether in Europe or in the colonies, the objects of parenting, of course, were both male and female too, and the same kinds of gendered visions as were applied to parents influenced the ways in which fathers and mothers approached their offspring. In the Victorian universe of the early twentieth century, parents imposed diametrically opposed expectations upon their sons and daughters, and parents perceived little girls, on the whole, as requiring more protection than their brothers. In the eyes of fathers especially, daughters deserved greater indulgence and needed less educational discipline but, paradoxically, they were also more mysterious and difficult to understand.

Many colonial administrators, who were always male, imagined Asia as unfathomable—or, in Raymond Schwab's words, as "the nocturnal figure of the mind" - whereas they envisioned the physical terrain of colonial administration as a Pandora's box, the ultimate symbol of feminine inscrutability. ${ }^{17}$ In Western eyes, native women represented the primordial mystery of indigenous cultures in Asia, in general, and the enigma of colonial arenas, in particular, since women and their families embodied the opaque village communities of indigenous society. Accordingly, it was only the scientific scrutiny of Western men that could decipher the conundrum of colonial governance. Knowledgeable civil servants should strip away the layers of secrecy and ignorance that surround the desa, said the Dutch adat specialist Cornelis van Vollenhoven in 1909; only through a scholarly ethnographic analysis of the customs and cosmology of family life in the desa can the great divide between the formal colonial state and the informal village world be bridged. ${ }^{18}$

As in Freud's conception of psychoanalysis, where a male psychoanalyst's insights disclosed the hidden secrets and solved the riddle of suppressed desires to heal female hysteria, the "imperial gaze" of white colonial administrators penetrated indigenous societies in order to expose the truth and to bring enlightenment. ${ }^{19}$ In North Africa, the trope of "the unveiling of Algeria" revealed the French longing to re-dress its colonial domain in modern French cultural attire after she had been exposed and domesticated. Women's withdrawal behind the veil served to protect the sovereignty of village communities and the integrity of indigenous traditions; the French craving to remove it by force underscored what Frantz Fanon has called "the historic dynamism of the veil." 20 Anticolonial oratory proceeded to invert these metaphors by placing the uncovered and defiant female body at the center of the anticolonial struggle.

Clearly, nationalist intellectuals, in the Dutch East Indies as in Algeria, employed the same gendered imagery in their influential assaults on colonial exploitation, but often they turned it upside down and inside out, even if the veil did not function as either a tangible or metaphysical emblem in the discourse of Indonesian nationalism before World War II.

\footnotetext{
16 lbid., p. 4.

17 Raymond Schwab, The Oriental Renaissance. Europe's Rediscovery of India and the East, 1680-1880, tr. Gene Patterson-Black and Victor Reinking (New York: Columbia University Press, 1984), p. 484.

18 Cornelis van Vollenhoven, Miskenning van het adatrecht. Vier voordrachten aan het Nederlandsch-Indisch bestuursacademie (1909: Leiden: Brill, 1926), pp. 16, 40.

19 Ella Shohat, "Imaging Terra Incognita: The Disciplinary Gaze of Empire," Public Culture 3, 2 (Spring, 1991): 64-65, and Winifred Woodhull, "Unveiling Algeria," Genders 10 (Spring, 1991): 112-31.

${ }^{20}$ Frantz Fanon, "L'Algérie se dévoile," in Sociologie d'une révolution (Paris: Maspero, 1968), p. 23. See also the defiant photographs of unveiled Algerian women in Marc Garanger, Femmes algériennes 1960 (Paris: Contrejour, 1982).
} 
Many of them argued that colonial rulers did not want the natives to perceive colonial rule as a tender, loving mother engaged in protecting her child from a hostile environment, but rather, as a mother who shields her fundamentally perverse offspring from committing suicide and giving free rein to its evil instincts. "The colonial mother protects the child from itself, from its ego, its physiology, its biology, and its own unhappiness. . .."21

Native intellectuals, it seemed, intentionally conjured up an oxymoron: by representing European rule as a cruel mother, they invoked a wide range of disturbing and contradictory images. Notions of natural and loving motherhood were corrupted by use of emblems of colonial regimes as Medea, for example, or as a female incarnation of l'état minotaur-the gluttonous mother country, always hungry for raw materials-devouring her own children. But in addition to paradox, pathos also surrounded this symbolism, since socialists envisioned revolutions, too, as political tranformations whose bountiful and utopian promises degenerated into the consumption of their own progeny. Tan Malaka in the early 1920s, for instance, used a well-worn cliché, to convey poignantly his shattered political dreams, when he observed that the Revolution in Russia, as had previously occurred during the French Revolution, "was devouring its own children."22

At the same time, in their representation of the colonized peoples themselves, anticolonial intellectuals employed a feminine allegory, comparable to the one invoked by European colonial discourses albeit with a sinister twist. While European civil servants, aided and abetted by their superior scientific knowledge from the West, saw themselves as uncovering and exposing the feminine mysteries of indigenous societies, nationalists depicted colonized peoples as vulnerable women, ravaged, tortured, and raped by Europeans. ${ }^{23}$ As Jawaharlal Nehru proclaimed about the British treatment of India: "[Englishmen] seized her body and possessed her, but it was a possession of violence. They did not know her or try to know her. They never looked into her eyes, for theirs were averted and hers cast down through shame and humiliation." 24 Coerced to reveal their involuntary nakedness like "strip tease artists," women personified the plight of all colonized people by being reduced to reluctant "centerfold[s] to the imperial voyeur." 25 The fragile physiology and psychology of colonized peoples-which presumably compelled the colonial mother to protect them from their own self-destructive "involution"-was thus transformed into an eroticized and mutilated female body.

21 Frantz Fanon, The Wretched of the Earth, tr. Constance Farrington (New York: Grove Weidenfeld, 1963) p. 211.

22 Malek Alloula, The Colonial Harem, tr. Myrna and Wlad Godzich (Minneapolis: University of Minnesota Press, 1986), p. 3, and Tan Malaka, From Jail to Jail, 3 vols, tr. Helen Jarvis. Southeast Asia Series, No. 83 (Athens, Ohio: Ohio University Monographs in International Studies, 1991): 1, 92. Tan Malaka referred to Georg Buchner's remark about the French Revolution: "The Revolution is like Saturn-it eats its own children."

23 Frantz Fanon, A Dying Colonialism, tr. Haakon Chevalier (New York: Grove Wiedenfeld, 1967), p. 66. Nationalist leaders in India, too, used the helpless native woman as an emblem of the beloved motherland the colonizers had pillaged and ravaged. See: Chandra T. Mohanty and Satya P. Mohanty, "Contradictions of Colonialism," The Women's Review of Books 7, 6 (March 1990): 19; and Chandra Talpade Mohanty, "Cartographies of Struggle. Third World Women and the Politics of Feminism," in Third World Women and the Politics of Feminism, ed. Chandra Talpade Mohanty, Ann Russo, and Lourdes Torres (Bloomington: University of Indiana Press, 1991 ), pp. 1-47. 24 Quoted by Sara Suleri, The Rhetoric of English India (Chicago: University of Chicago Press, 1992), p. 17.

25 Aimé Césaire, Introduction, in Victor Schoelcher, Esclavage et colonisation (Paris, P.U.F., 1948), p. 7, and Ann Laura Stoler, "Carnal Knowledge and Imperial Power: Gender, Race, and Morality in Colonial Asia," in Gender at the Crossroads: Feminist Anthropology in the Post-Modern Era, ed. Micaela di Leonardo (Berkeley: University of California Press, 1991), p. 54. 
Accordingly, when Tjipto Mangoenkoesoemo caricatured prevailing notions of proper motherhood, he incorporated complex layers of meaning: simultaneously, he elicited the primordial duality of woman as Madonna, on the one hand, and Whore, on the other. The colonial state was both a mercenary harlot and a mean-spirited mother, Tjipto implied in the Indonesian Volksraad in 1918, who sold her favors to the highest bidder, thereby serving the interests of rapacious European capitalists, while muzzling or sowing discord among her native offspring.

Quite predictably, the ubiquitous trope of the malicious and evil stepmother entered the discourse, too. When De Standaard, the journal of Dr. Abraham Kuyper's Anti-Revolutionary Party, accused the European residents of the Indies who regarded the archipelago as their "fatherland" of harboring a "love for the mother country barely above the freezing point," the magazine of the Indies blijver association "Insulinde" responded with cynicism. Love for the mother country is a beautiful word but a vague notion, Insulinde argued, stating that mere respect for our fatherland should suffice. It is shameful to ask permanent Indies residents to love a mother country which has never shown her children across the ocean any affection. How can they adore a mother country, which has treated them in nothing but the most blatant "stepmotherly fashion?"26 De Beweging in 1921, for its part, switched genders and struck a "stepfatherly" theme. If it is really true that the Dutch colonial government wants to be a father to our Indies, De Beweging inquired rhetorically, then he will have to make amends and treat his children with "love and devotion, with compassion and patience" as is proper for a good and thoughtful father. If he conducts himself like "a heartless stepfather or fosterparent [stiefvader or voogd]," his children will fear him and tremble at at the sight of him, rather than bear him affection or respect. ${ }^{27}$

Tjipto's contemporary, Soetatmo Soeriokoesoemo-despite his disagreement with Tjipto about the essence of Javanese culture and its proper response to European values-also represented Dutch rule in gendered terms. The capitalist state, wrote Soetatmo, resembled a family consisting of a father "henpecked" by a mother, who does nothing but primp herself while neglecting her obligations to her children. ${ }^{28}$ Some of these children, meanwhile, wished to assert their autonomy from Dutch parentage altogether. Semaoen, for example, conceded in 1924 that the Communist movement might still be callow and inexperienced, but he insisted that it had already achieved the status of a willful and independent young adult, who does not wish to be "a child of the Dutch but only a child of Leninism." 29 Semaoen clearly implied that Indonesians were no longer malleable infants but instead, vigorous young men and women quite capable of selecting their own mentors.

In juxtaposition to a manipulative imperialist parent who provoked rancor and bitterness among his or her flock of children-divide et impera-Soekarno, in his theatrical courtroom defense during his political trial in 1930, also concocted a distinctly female alternative, but in his case he summoned an attentive mother figure who fosters brotherhood and sis-

\footnotetext{
26 H.B., "De Standaard over het 'Insulinde' Personeel," Insulinde 1, 15 (August 1, 1910): 4-5. One of the colorful tea planters in the Preanger in Hella Haasse's very recent Heren van de thee (Amsterdam: Querido, 1992)-as the epilogue argues, a novel grounded in fact, not fiction-denounces the Netherlands" "stepmotherly" treatment of the Indies as an "unassailable fact and a scandal, a crying shame," p. 142.

27 De Beweging [Algemeen Politiek Weekblad] 3, 7 (February 12, 1921): 100.

28 Soetatmo Soeriokoesoemo, Sabdo-Panditto-Ratoe: het recht is van den wijze (Weltevreden: Indonesische Drukkerij, 1920), p. 3, quoted by Takashi Shiraishi, "The Disputes between Tjipto Mangoenkoesoemo and Soetatmo Soeriokoesoemo: Satria vs. Pandita," Indonesia 32 (October, 1981): 101.

${ }^{29}$ Ruth T. McVey, The Rise of Indonesian Communism (Ithaca: Cornell University Press, 1965), p. 252.
} 
terhood among her children: the feminine allegory of Goddess Merdeka, who instructs us in the sacred knowledge "United we stand, divided we fall." ${ }^{30}$ Similarly, in the postwar independence struggle, a postcard disseminated in Java in 1945 or 1946, celebrated the international solidarity of Indonesians with their nationalist siblings in India with the caption "We Fight for Mother's India and Mother's Indonesia"31 (see figure 1). After Soekarno and Hatta unilaterally proclaimed the nation's autonomy on August 17, 1945, it was no suprise that India was one of the very first nations to recognize Indonesia's independence. In a certain way nationalists in both Indonesia and India had committed rhetorical matricide-or patricide, for that matter. Without equivocation they rejected the abusive and withholding European mother country, whether Great Britain or the Netherlands-which represented, in the postwar period, nothing but fear of renewed exploitation-and transferred their unwavering allegiance to a mother figure who sheltered her native sons inside their tropical domain in Asia; inevitably only the latter was worthy of their filial obedience and emotional support. Thus the postcards Pemoeda2 pertahankan tanah air dengan djiwa ragamoe, Bersoenoenan bahoe oentoek kesempoernan kemerdekaan Indonesia, and Awas!! pengchianat bangsa called upon all young men "to defend the Indonesian mother country with body and soul," or "to stand shoulder to shoulder to perfect Indonesian independence" and to "beware of the traitors of the people" (see figure 1).

The Japanese during World War II, however, had again reinforced the trope of the destructive female when they circulated propaganda portraying the Dutch colonial state as a diabolical "temptress," whose seductive appearance disguised the fact that she was a genuine monster at heart (see figure 2). Following the defeat of Japan and the return of Dutch civil servants in 1945, Indonesian nationalists also conjured up this negative female symbolism, making it quite explicit in their representation of the Netherlands Indies Civil Administration as a tawdry prostitute. A postcard with a cartoon of a scantily dressed white woman revealed the caption: "Beware: do not be tricked by the whore N.I.C.A. ... [Later she will oppress our Indonesia!]" (Awas! djangan terpedaja dengan pelatjoer N.I.C.A. . . Inanti Indonesia kami aniaja!] ) (see figure 1).

Parental metaphors, of course, whether referring to motherhood or fatherhood, were not unique to colonial settings. In the metropole, groups of European peasants and workingclass citizens were also depicted as unruly children in need of civic education before they could be integrated as full-fledged adult citizens. However, political elites in most European countries presumed that workers and peasants were speakers of the same national language, who would become more proficient in the nation's cultural grammar once they pulled themselves up by their bootstraps and recognized the benefits of capitalist democracy and electoral politics.

In contrast, civil servants dispatched to the colonies saw their native wards as preliterate, as not yet capable of intelligible speech, and most of them embraced one of two contending perspectives on their indigenous pupils. Professor J. C. van Eerde, the director of the Ethnology Section of the Colonial Institute in Amsterdam, for instance, articulated the dilemma succinctly in the context of the Indonesian archipelago: European impressions of less developed people, van Eerde wrote in 1914, tend to oscillate between two extremes. On the one hand, Westerners concoct a vision of primitive people as caught in a web of

\footnotetext{
30 Indonesia Accuses! Soekarno's Defense Oration in the Political Trial of 1930, tr. Roger K. Paget (Kuala Lumpur: Oxford University Press, 1975), p. 88.

31 "Mother's Indonesia and Mother's India" was most likely an awkward English translation of Ibu Indonesia dan Ibu India.
} 

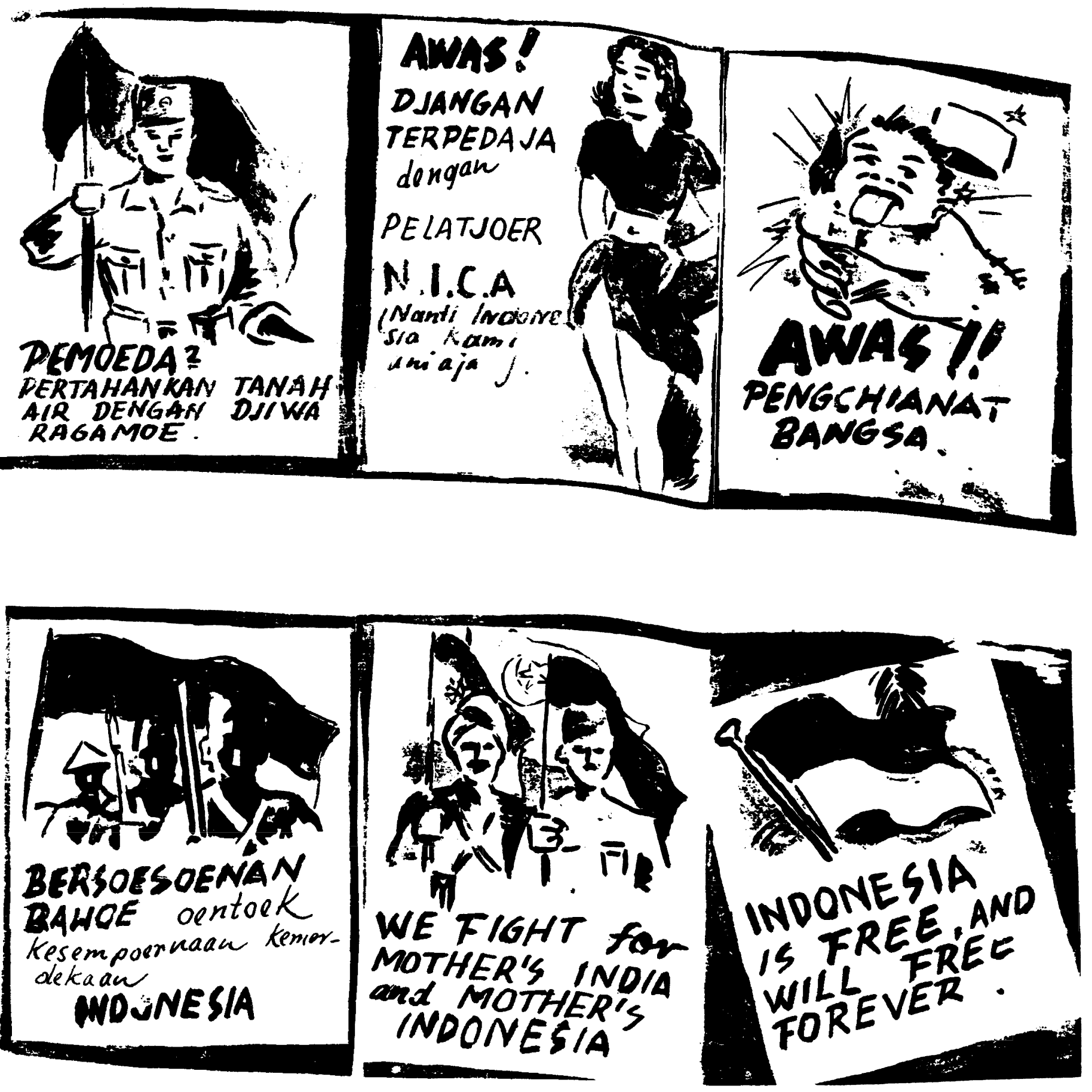

Figure 1. Nationalist Postcards with Propaganda. P. van Meel, Getekend als koloniaal. Een relaas over het leven van gewone mensen in het vooroorlogse Indie en tijdens de bewogen laatste jaren van het Koninklijk Nederlands-Indisch leger (Dordrecht: Stabelan, n.d.), p. 98. 


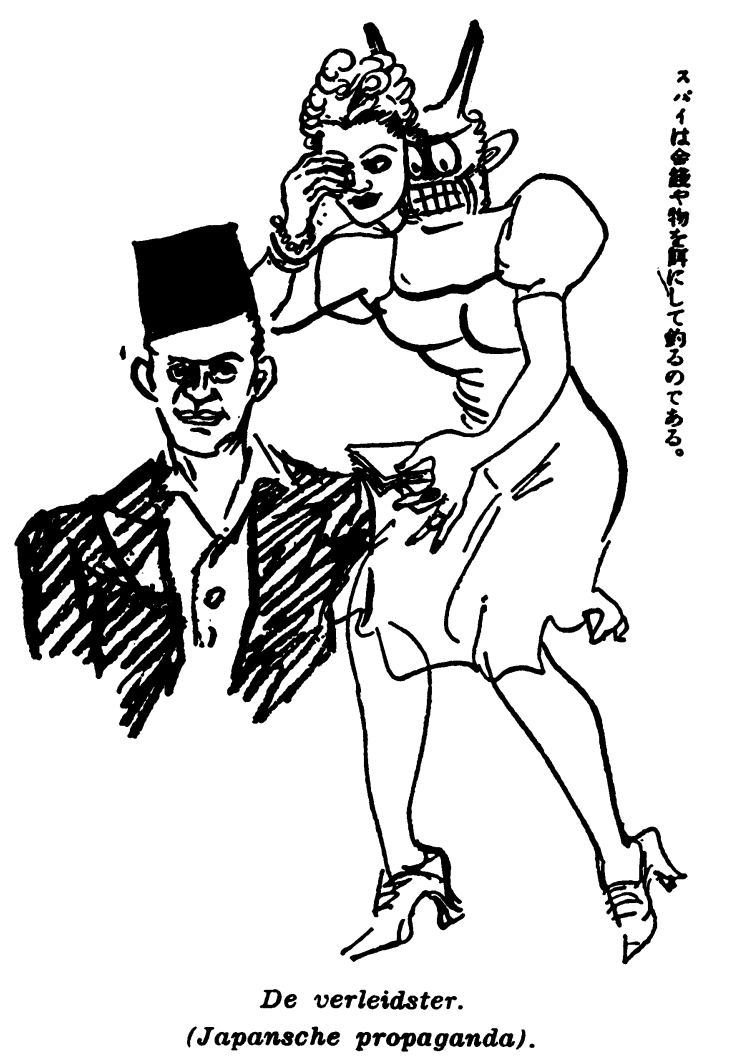

Figure 2. Japanese Propaganda during the Occupation of the Dutch East Indies. Het Indisch Nieuws, Algemeen voorlichtingsorgaan gewijd aan de overzeesche gebiedsdelen, 2, no. 46, December 7, 1946. 
"cruelty, magic, cannibalism, and slavery." On the other hand, they conjure up the idyllic image of people untainted by civilization, living in "dreamy tranquility and harmony in the mild climate of their natural environment." 32

The quixotic views of the latter extreme harked back to the Enlightenment and echoed Rousseau's vision of Emile or resembled Montesquieu's depiction of the good Troglodytes in his Lettres Persanes. Indeed, some hyper-ethical Dutch colonials did see the Javanese as genuine creatures of nature, who were virtuous, innocent, and capable of living in perfect accord as long as they were not tarnished by the evils of European civilization. Similar to Montesquieu's righteous Troglodytes, who were united by their good hearts and honorable souls as much as by the horrible corruption that surrounded them, idealistic Dutchmen in both the public and the private sector feared that only the nefarious influences from the West caused kromo to lose his unsullied purity and made him greedy, petulant, and untrustworthy. ${ }^{33}$ As the irrepressible opheffer Gonggrijp insisted in his fortieth letter to the Bataviaans Handelsblad in 1911: "the fundamental honesty of the genuine, oer kromo is truly touching." ${ }^{\prime 34}$

On the whole, however, the other extreme view prevailed, and Dutchmen more often perceived the Javanese as natives whose illiteracy issued from their immaturity or congenital stupidity; many Dutch colonials thought that the invidious basic instincts of the Javanese would forever lead them astray unless they were kept in check indefinitely. Thus, some civil servants' empathetic devotion to the pristine indigenous peoples, who, in their eyes, possessed a natural gentility and sweet disposition, clashed with other Dutchmen's contempt for superstitious and devious natives, whether from Java or the outer regions. The implication of these competing visions, of course, was a correspondingly contested discourse in which the "hyper-ethical" language of motherly affection and respect for local adat collided with a stentorian masculine voice calling for discipline, punctuality, and rigor.

Accordingly, in 1915 a Dutch military officer described the average Javanese as "a cowardly, unreliable, and indolent lout."35 An Indonesian representative, Radjiman, in turn, reminded his audience in the Volksraad in 1918, that the Dutch tended to see the average inlander - a perception riddled with contradictions-as "a bad and cruel coachman, a shoddy laborer, a lazy supervisor, a stubborn and backward peasant, an indifferent servant, and a brutal master. He is dishonest, stupid, careless, childish, despotic, and servile."36 Given these impressions of their native wards, stern fatherly guidance, schoolmasterish

32 J. C. van Eerde, Koloniale Volkenkunde; First Part: "Omgang met inlanders," Mededeeling No.1, Afdeeling Volkenkunde, No.1, Koninklijk Koloniaal Instituut (1914: Amsterdam: De Bussy, 1928), p. 48.

${ }^{33}$ Montesquieu, The Persian Letters, tr. George R. Healy (Indianapolis: Bobbs-Merrill, 1964), Letter XII, p. 25.

${ }^{34}$ G. L. Gonggrijp, Brieven van opheffer aan de redactie van het Bataviaans Handelsblad, 4th Edition (Maastricht: Leiter-Nypels, n.d.), p. 149; see also Rudy Kousbroek, Het Oostindisch kampsyndroom (Amsterdam: Meulenhoff, 1992), p. 137.

${ }^{35}$ Asymptoot (pseudonym for M.H. du Croo), "Kromo buiten," Indisch Militair Tijdschrift 46 (February, 1915); see Jaap de Moor, "De affaire Asymptoot en de haatzaai-artikelen," in Onderscheid en minderheid. Sociaalhistorische opstellen over discriminatie en vooroordeel aangeboden aan Professor Dik van Arkel, ed. Herman Diederiks and Chris Quispel (Hilversum: Verloren, 1987), pp. 285-302. Tjokroaminoto, in a speech to the Volksraad on November 14, 1918, referred to the publications of both van Haastert and Asymptoot, see Handelingen van de Volksraad, 1918, p. 177.

${ }^{36}$ Handelingen van de Volksraad, 1918, p. 171. In the index to the eerste gewone zilting, he was listed as Dr.Ng. Radjiman alias Wediodipoero. Radjiman quoted these views, articulated by the journalist Karel Wybrands in Het Nieuws van den Dag in 1910, in the context of the judicial prosecution but subsequent acquittal in 1915 of Mr. van Haastert. The latter had been charged with committing a persdelict (a violation of press laws) for using words identical to Wybrands's. 
instruction, and only an occasional motherly nudge were, indeed, the operative metaphors of the Dutch Civil Service in the East Indies which "brought the Pax Neerlandica, and with it peace and justice, the possibility of a rise in the standard of living, and the sense that millions of ethnically diverse people are all children of one mother country, [Dutch] Indonesia." Twentieth-century Dutch colonials, meanwhile, chided Indonesian nationalists for thinking "in a childlike and childish fashion that they were called upon to replace the foreign colonial masters." When Soekarno, for instance, intimated in a humorous figure of speech that daybreak does not come because the rooster crows but, rather, the rooster crows because the sun is rising, he and other nationalists were dismissed as infantile and misguided roosters who think that by "crowing tumultuously they can accelerate daybreak."37

Nationalist ideas of independence and autonomy, pontificated the conservative Dutch civil servant van der Jagt in the Volksraad in 1918, were nothing but symptoms of innocent childhood diseases, which the Dutch had to tolerate as "the measles and chickenpox of a primitive people yearning for progress." 38 Like a pediatric nurse the Dutch administration would care for her young patients during the maladies of childhood; she would hover over their sickbed until an omniscient doctor, steeped in Western medical science, might declare them fully recovered and ready to commence an independent life. In 1939 the British historian John Sydenham Furnivall, in fact, humorously portrayed the overly didactic quality of Dutch colonialism, personified by zealous guardians who could not refrain from telling their orphans what to do, even when the latter were quite capable of taking care of themselves. ${ }^{39}$ And at the end of World War II, after the proclamation of the Indonesian Republic on August 17, 1945, the very last governor-general of the Dutch East Indies used the same didactic language by noting that the prestige of the Netherlands [in Indonesia] could be compared to "a schoolmaster in his classroom two days before the summer vacation." 40

Obviously, gendered metaphors illuminated notions of command and subordination, only to mask the blatant discrepancies of power between the Dutch and their Indonesian subalterns by using the euphemistic language of caregiver and patient, of parent and child, or of schoolteacher and pupil. While mostly paternalistic in tone and designed primarily to justify the harsh measures necessary to teach common sense to indigenous peoples, colonial discourse appealed to feminine images if and when it wished to emphasize the altruistic attempts of the West to improve the material standard of living and to protect native peoples from archaic traditional practices. The government's concern with the welfare of the native population was so deeply felt, said a former civil servant, that it displayed an "exaggerated baboeism": the colonial government's nurturing qualities, rather than its shortcomings, spawned the Indonesian Revolution. ${ }^{41}$ The Dutch nation, after all, was a greenhouse dedicated to the cultivation of the familial bonds of the average native household,

\footnotetext{
${ }^{37} \mathrm{Ph}$. Coolhaas, "Ontstaan en groei," in Wij gedenken ... Gedenkboek van de vereniging van ambtenaren bij het binnenlands bestuur in Nederlands-Indie (Utrecht: Oosthoek, 1956), pp. 62, 70; the Dutch words are kinderlijk and kinderachtig; and Hendrik Colijn, Koloniale vraagstukken van heden en morgen (Amsterdam: de Bussy, 1928), p. 34, quoted in Bernard Dahm, Soekarno en de strijd om Indonesie's onafhakelijkheid (Meppel: Boom, 1964), n. 364, p. 341. 38 van der Jagt, Memoires, Appendix, p. 342. Speech in the Volksraad, November 15, 1918.

39 J.S. Furnivall, Netherlands India. A Study of Plural Economy (Oxford: Oxford University Press, 1939), p. 389. See also Rob Nieuwenhuys, Mirror of the Indies. A History of Dutch Colonial Literature, tr. Frans van Rosevelt (Amherst: University of Massachusetts Press, 1982), pp. 157-58.

${ }^{40}$ D.U. Stikker, ed., Jhr. Mr. Dr. A.W.L. Tjarda van Starkenborch Stachouwer: bijdragen tot een kenschets (Rotterdam: Donker, 1978), p. 20.

41 D.H. Burger, "Het binnenlands bestuur op Java en Madoera," in Wij gedenken, p. 100.
} 
because the weak economic conditions of the Indonesian population emanated primarily from "a loose family life." 42

Implicit in this observation was a sense that women, while they were crucial to Indonesians' economic well-being, should nonetheless be encouraged to embrace exclusively their domestic roles. Uniquely Western definitions of domestic propriety and prosperity prompted Dutch colonials to blame Indonesian women as much as men for failing to construct stable households. Women, they argued, devoted too much time and energy to working in the fields, to harvesting and processing rice, or to selling produce in the marketplace, which prevented them from fulfilling their maternal destiny. The Dutch employed tortured logic, however, in their efforts to understand the sexual division of labor among Indonesians and its relationship to the prevailing lack of economic development. Javanese men, a Dutch cliché proposed, were economically "carefree, artistic, impulsive, rarely and irregularly active." 43 Besides, men in Java and elsewhere failed to muster the same kind of "inner impulse" (innerlijke aandrift), "serious determination" (ernstige wil), or "sense of duty" (plichtgevoel) as men in the West to provide for their families; as a result, women and children had to survive, by hook or by crook, on their own. ${ }^{44}$ But when a heroic woman worked like an ox, day and night, to generate food and sustenance for her family, she was held liable for the "loose family life" of the indigenous population, which, in Dutch eyes, was the root cause of Indonesians' lesser economic development. This kind of perverse tautological reasoning revealed, above all, that the Dutch habit of viewing the role of Indonesian women through a Western looking glass blurred their vision and impeded their logical speech.

Tjipto Mangoenkoesoemo, for his part, confirmed the centrality of women in Indonesian society when he said in the Volksraad that "women in our country, as we all know, are much more instrumental in the functioning of our social life than are women in Europe," but he drew diametrically opposed inferences. Because they played such a pivotal role in the hustle and bustle of daily life and the perennial struggle for survival, he noted, women should not be disenfranchized but, instead, ought to receive an actual voice in the running of the body politic. ${ }^{45}$

In contrast, when Dutchmen employed a feminine vocabulary in their allusions to colonial rule as a "birthplace," a "cradle," or a "public nursery" devoted to the promotion of the vitality, maturity, and eventual independence of Indonesian people, they nonetheless implied that this was an arena in which men wielded control. To continue the medical metaphor introduced by van der Jagt in the Volksraad in 1918, the Dutch colonial government functioned as a nurse during her patients' childhood infirmities, but it was a distinctly male pediatrician who finally declared them healthy enough to sanction their release from the hospital. While the caring qualities of colonial rule could be rendered in terms of tradi-

\footnotetext{
$42 \mathrm{Mr}$. Creutzberg's address to the Indisch Genootschap in the late 1920s, quoted in A.D.A. de Kat Angelino, Colonial Policy, 2 vols., tr. G.J. Renier (Chicago: University of Chicago Press, 1931): 2, 226.

43 G.J. Gonggrijp, “Het arbeidsvraagstuk in Nederlandsch-Indie,"Koloniaal Tijdschrift 14 (1925): 482-522, 618-48, quoted by Jennifer and Paul Alexander, "Protecting Peasants from Capitalism: The Subordination of Javanese Traders by the Colonial State," Comparative Studies in Society and History 33, 2 (April 1991): 373.

44 The term "ernstige wil" was used in an explanatory memorandum to the Volksraad in 1925 regarding the proposed legislation to curtail women's work at night between 10 PM and 5 AM. See: Handelingen van de Volksraad, 1925, Eerste gewone zitting, Onderwerp 6, Stuk 3, Memorie van Toelichting, p. 7. H.E.B. Schmalhausen used plichtgevoel and innerlijke aandrift in Over Java en de Javanen. Nagelaten geschriften (Amsterdam: van Kampen, 1909), p. 49.

45 Handelingen van de Volksraad, 1918, Eerste gewone zitting, Begrooting van Nederlands Indie voor het dienstjaar 1919, Algemene beschouwingen, 5e vergadering, 19 June, 1918, p. 125.
} 
tional women's professions, such as social work and nursing, the ultimate decisions about the patients' future remained a male prerogative. Again, Dutch colonials imposed Western standards regarding the appropriate arenas for men and women upon the Indonesian archipelago, and the gendered description of colonial governance echoed Victorian ideology. "Private family life rather than the public sphere constitutes the proper domain for women to develop their gifts and talents," the Dutch member van Helsdingen warned the Volksraad in 1935, 'because women's desire to be men's equal degenerates, only too soon, into doing what men do-that is, being their equal in smoking and drinking." 46

Bearing the burden of colonial governance was clearly a masculine task, and Dutch colonial discourse tended to portray even the efforts of hyper-ethical civil servants, who may have tried to nourish the welfare of Indonesians with a charitable commitment resembling motherly devotion, in paternalistic terms. Discussions of colonial rule appealed, on occasion, to the cosmology of the world of wayang which, aside from such female characters as the exquisite but cunning Sumbadra, the all-embracing Draupadi, the more passive Sinta, or the feisty Srikandhi-whose gender identity was more equivocal — was also a uniquely masculine imaginary universe. In Eduard du Perron's "Open Letter" to Sutan Sjahrir, for instance, published in the progressive magazine Kritiek en Opbouw on August 16, 1939, he alluded to the poignant dilemma broad-minded and liberal Dutch men and women confronted in Indonesia in the 1930s, the final decade of an unrepentant colonial regime. Those Dutchmen who had labored zealously in the idealistic salt mines of the ethical policy, said du Perron, were now in the curious position of having dedicated their lives to "uplifting" Indonesians, only to want to suppress the tangible results of their very own success once Indonesians asserted their right to go it alone. On the other hand, if they were to continue their educational efforts on behalf of Indonesians it implied they would stand united with their pupils in opposition to their Dutch "brothers."

This quandary, according to du Perron, yielded neither a pragmatic accommodation nor an honorable solution. In the end, said du Perron in a reference to the Mahabharata, the only proper stance for Dutch colonials in Indonesia in the late 1930s, if they are sincere and realistic, is to accept the role of Drona, the beloved teacher of the Pandawa who taught them all they needed to know to engage in battle with their eternal enemies, the Kurawa. Since Drona originally hailed from the other side, the Pandawa could not fail to wonder once the war finally erupted: "must we kill him, our goeroe?" And they decided: "Yes! Because he belongs to our enemies!" So they killed him, but when he was dead, they buried him with the greatest deference and the warmest affection. ${ }^{47}$

Indonesians, for their part, invoked similar wayang imagery. In the 1920 s the moderate Indonesian nationalist Margono Djojohadikusumo gave an introduction to a wayang orang performance in central Java, staged specifically to raise money for a new Kartini school. The performance focused on a part of the Ramayana that featured Rahwana's brothers, Wibisana and Kumbakarna, in the wake of the evil giant's abduction of Sinta, Rama's wife. Wibisana and Kumbakarna urged their brother Rahwana to return Sinta to her husband Rama-who was, after all, the incarnation of the God Vishnu and the protector of wisdom and justice.

\footnotetext{
46 Handelingen van de Volksraad, 1935-1936, Eerste Gewone Zitting, Begrooting van Nederlands-Indie voor het dienstjaar 1936, Algemeen gedeelte, 10e vergadering, 13 July, 1935, pp. 192-93.

47 Eduard du Perron, "Open Brief aan een Indonesier," reprinted in Indonesia (Weekblad van Perhimpoenan Indonesia) 16, 24 (December 1, 1945). Du Perron did not mention that, despite the raging war in progress, both the Kurawa and Pandawa temporarily halted their heroic struggle in order to bestow a grand funeral upon Drona; see Benedict R. O'G Anderson, Mythology and the Tolerance of the Javanese (Ithaca: Cornell Modern Indonesia Project, 1965), pp. 19-20.
} 
When his malevolent brother refused, Wibisana left the Kingdom of Langka, Rahwana's domain, to offer his services to Rama instead. Although he did not wish to protect the honor of his sinister brother, Kumbakarna, he stayed on to defend the integrity of his native land, where he eventually died in battle.

However, when Rama's arrow struck the gigantic Rahwana, allowing Rama not only to win Sinta back but also to gain control of Rahwana's realm, he asked Wibisana to rule his dead brother's kingdom of Langka. In his discussion of the plot, Margono likened Mr. Th. van Deventer, one of the Dutch progenitors of the Ethical Policy, to Wibisana; a decent and humane Dutchman such as van Deventer, Margono proclaimed, was a modern personification of Wibisana. ${ }^{48}$ Kumbakarna, too, reappeared in a twentieth-century Dutch incarnation: the archeologist Pieter Vincent van Stein Callenfels, whose enormous girth and stature were of legendary proportions, reminded Indonesians of a lakon from the first main story of the Arjoena-Sasra-Baoe cycle which described Kumbakarna as having "a body that resembled a mountain, eyes that burned like the midday sun and a voice that sounded like a thousand claps of thunder." 49 It did not dawn on Dutchmen such as du Perron or Indonesians such as Margono, however, to use the tough Srikandhi or the smart Sumbadra as metaphorical characterizations of the heroic struggle of Indonesian nationalism against Dutch colonial rule.

Curiously, feminine allegory figured more straightforwardly in the justification of the "colonial sub-imperialism," to use Fieldhouse's phrase, that took place in the archipelago around the turn of the century. ${ }^{50}$ Advancing the imperial interests of the mother countrynot only the Netherlands under the scepter of a sequence of female monarchs, but also Queen Victoria's British empire-was often articulated in the Victorian idiom of maternal solicitude: non ministrari, sed ministrare (to minister, not to be ministered unto). ${ }^{51}$

For instance, the military expeditions to bring the Outer Regions within the administrative sphere of the Dutch colonial state in the 1890 s were rationalized by appealing to the nation's protection of the honor of the two beloved women of the Dutch royal family-Queen Emma and her daughter, Princess Wilhelmina, who would succeed her a few years later. The legitimation of the 1894 military campaign to subdue the island of Lombok was couched in Victorian language that represented the Dutch troops as white knights in shining armor who guarded the feminine chastity especially of Princess Wilhelmina, who was only 14 years old at that time-rhetoric that fused with the oratory of militant nationalism. The youthful purity of Princess Wilhelmina functioned as a tangible symbol of Dutch national prestige in its confrontation with a perfidious enemy, and public opinion in the Netherlands celebrated the imperialist incorporation of Lombok into the Dutch colonial state by invoking "ethical" arguments and the need to defend innocent royal womanhood. ${ }^{22}$ Fifty years later, in the

\footnotetext{
48 Margono Djojohadikusumo, Herinneringen uit drie tijdperken. Een geschreven familie overlevering (Amsterdam: Gé Nabrink, 1970), pp. 82-83.

49 B.D. Swanenburg, Iwan de verschrikkelijke. Leven en werken van Dr. P. V. Stein Callenfels (Maastricht: Leiter Nypels, 1951), p. 43.

50 David Kenneth Fieldhouse, Economics and Empire, 1830-1914 (Ithaca: Cornell University Press, 1973).

51 This Victorian motto is emblazoned in the official crest of Wellesley College, founded in the late 1870 s.

52 J. van Goor, "De Lombokexpeditie en het Nederlandse nationalisme," in idem, ed., Imperialisme in de marge. De afronding van Nederlands Indie (Utrecht: HES, 1986), pp. 49, 62. Robert R. Westbrook, in "I want a Girl, Just Like the Girl that Married Harry James: American Women and the Problem of Political Obligation in World War II," American Quarterly 42, 4 (December, 1990): 587-614, also explored the gendered imagery of American soldiers' definition of private obligation as far as fighting against foreign aggression was concerned, and notes that when
} 
very different context of the Indonesian independence struggle, a US State Department official described the intransigent refusal of the Dutch to listen to Indonesian nationalists' demands as being like the complaint of a headstrong mother who, while visiting her soldier son, believed that "the whole regiment was out of step" except for her beloved child. ${ }^{53}$

In general, gendered symbolism infused the rhetoric of languages other than Dutch, whereas maternal and paternal imagery also permeated the jargon of religious proselytizers who, in most instances, were involved in a distinctive form of colonialism, too. Franciscan friars, for instance, struggling to convert Pueblo Indians in seventeenth-century New Mexico, talked in a quaintly androgynous fashion about God's compassion and His desire to suckle the Indian heathens with "the mother's milk of the Gospel" and to nurse them at "the bosom of the Church." 54

Officials of the British colonial service also viewed their subjects as naive and gullible, and saw themselves as thoughtful young men who ministered to their colonial wards with maternal warmth and tenderness and offered "the resources of the mother country to the service of these latest of her children." 55 These natives possessed, according to a 1927 report written by a colonial recruitment officer, uncanny powers of intuitive observation; "Like children, they instinctively 'size up' the men they are dealing with..."56 But the men and women of the colonial service, intoned Arthur Creech Jones, the British Secretary of State for the Colonies as late as 1949, are expanding the frontiers of civilization, but above all, they are the servants, counselors, and friends of the peoples among whom they live and work. 57

On the whole, however, it seemed that the British were more concerned with personal status, whereas the Dutch were preoccupied with their collective survival as a small enclave of white men and women amidst a sea of brown faces. Dutchmen in Africa, too, argued that white settlers were few and far between on a pitch black continent, and they were convinced that their extinction could only be averted through unconditional white solidarity and the suppression of the least sign of native resistance. The Dutch in diaspora-steadfastly convinced of the "substantiality of things," as Johan Huizinga has said-tried to nail down the world, as if to anchor social relations with the colonial "other" in a terra firma impervious to floods and natural disasters. ${ }^{58}$ Whether in Europe or in the complex colonial settings of Southeast Asia or Africa, the Dutch tended to erect monolithic "Citadels" bastions of horizontal as well as vertical solidarity designed to defend themselves more

"American soldiers said ... that it was American women they were fighting for ... they articulated the moral obligation of the 'protector' for the 'protected,'" p. 592.

53 Quoted in Gerlof D. Homan, "The Netherlands, The United States and the Indonesian Question, 1948," Journal of Contemporary History 25, 1 (January, 1990): 132.

54 Ramon A. Gutierrez, When Jesus Came, the Corn Mothers Went Away. Marriage, Sexuality, and Power in New Mexico, 1500-1846 (Stanford: Stanford University Press, 1991), pp. 77-78.

55 Charles J. Jeffries, The Colonial Empire and its Civil Service (Cambridge: Cambridge University Press, 1938), p. 18. But critics of British imperialism on the left, such as Ramsay MacDonald, excoriated the British pretense at mission civilisatrice; an indigenous person, MacDonald said, "may be a child, but he is a child with a social inheritance. He is not a thing to bend at will." See J.R. MacDonald, "The Propaganda of Civilisation," International Journal of Ethics 11, 4 (1901): 459.

56 Sir Ralph Furse, Aucuparius. Recollections of a Recruiting Officer (London: Oxford University Press, 1962$),$ p. 142.

57 Foreword by Arthur Creech Jones, Secretary of State for the Colonies, to Sir Charles Jeffries, Partners for Progress. The Men and Women of the Colonial Service (London: Harrap, 1949), p. 6.

58 Zbigniew Herbert, Still Life With a Bridle. Essays and Apocryphas (New York: The Ecco Press, 1991), and Edward Hirsch, "The Fidelity of Things," The New Yorker, December 23, 1991, p. 104. 
effectively against the many dangerous exterior forces lurking around them. ${ }^{59}$ In South Africa, the Voortrekker monument in Pretoria, commemorating the Great Trek of Dutch Boers into the hinterland in 1838 , seems to give physical shape to this citadel mentality: resembling a medieval fortress, with walls as thick as the Maginot line, it serves not only as a tangible remembrance of the Afrikaner past but also as a vade mecum to the Afrikaner mind and collective imagination. ${ }^{60}$

The feudal spirit of British colonial seigneurs vis à vis other European colonizers, in contrast, prompted them to protect their own indigenous vassals and retainers against, as it were, "rival barons," a misguided chivalry that the Dutch interpreted as a pathetic lack of white-skinned fellowship and "a base betrayal." 61 British colonials in India, especially in the period after the Mutiny, approached their imperial domain in Asia as a feudal order which they could oversee most effectively by harking back to their own history of feudalism in the middle ages; Englishmen envisioned the Indian present-as if through a Darwinian evolutionary prism-as a modern repetition of their own medieval past. British colonials contended that England had matured in a linear fashion from a fractured feudal society, when it was dominated by fiefdoms, dynastic struggles, and subsistence agriculture, into a progressive democratic and industrialized nation-state. Referring to the biologist's claim that "ontogeny recapitules phylogeny," they conceded that the same might be possible for India in the long run, but this would occur only if the British continued to tutor their Indian charges properly. 62

Dutch colonial residents in the twentieth-century Indies, however, could not fathom an organic connection between the Dutch past and the Indonesian present. Perhaps because the western Low Countries had been one of the rare regions in medieval Europe not to develop an elaborate system of fiefdoms and vassalage, Dutch historical memory could not conjure up a medieval past in Holland that rendered the patrimonialism and feudal privileges of the Javanese aristocracy more intelligible or familiar. Rather, Dutch colonials remembered a national history characterized by centuries of struggle to protect little Holland's "own square foot of ground," not only against the threatening elements of nature but also against the realpolitik pursued by its gigantic and powerful neighbors on the European

\footnotetext{
59 Arjo Klamer, in Verzuilde dromen. 40 jaar SER (Amsterdam: Contact, 1990), has elaborated on the metaphorical representation of Dutch mentalité as "a citadel." The Dutch citadel, Klamer argues, is small and the menace from the outside is great. In the past, floods and inundation as well as Spanish military might imperiled the Dutch citadel; today, foreign competition and environmental pollution endanger it. Within the Dutch citadel, therefore, people have to help each other's survival through cooperation, deliberation, and family solidarity: Eendracht maakt Macht (Power in Unity). At the same time, the collective struggle against "the other without," such as Indonesians or Africans in a colonial context, reinforces the collective strength and internal cohesion of the Dutch citadel, pp. 174-76. See also: Ernest Zahn, Regenten, rebellen, en reformatoren. Een visie op Nederland en Nederlanders (Amsterdam: Contact, 1989) for a similar argument.

60 Donald Harman Akenson, God's Peoples. Covenant and Land in South Africa, Israel, and Ulster (Ithaca: Cornell University Press, 1992), chapter 3.

61 Elspeth Huxley, The Flame Trees of Thika (New York: Penguin, 1962), p. 51.

62 Bernard S. Cohn, in "Representing Authority in Victorian India," in The Invention of Tradition, ed. Eric Hobsbawm and Terence Ranger (Cambridge: Cambridge University Press, 1983), pp. 166-67. Cohn also notes, however, that the British were equally convinced that Indians' weakness and incompetence had made them unsuitable for self-rule and had caused the sub-continent to be subjugated by a sequence of foreign rulers, the last of which were the English. The French, in contrast, saw their colonies as champs d'éxperience, as primitive experimental terrains where they could carry out controlled tests, designed to identify universal principles of social organization by comparing their functioning in a variety of distinct cultural settings; see Gwendolyn Wright, The Politics of Design in French Colonial Urbanism (Chicago: University of Chicago Press, 1991), passim.
} 
continent. ${ }^{63}$ Above all, however, Dutch historical memory was intertwined with the impetuous North Sea, which surrounded the small nation and became a lucrative source of wealth through shipping and maritime trade during the Dutch Republic's Golden Age. But the North Sea also represented doom and disaster, since it threatened at all times to inundate the water-logged provinces of the Low Countries. In the colonies, too, Dutch men and women were enveloped and imperiled, not by water but by an ominous ocean of black or brown faces, which seemed ready to be whipped into a frenzy, at any moment, by a violent "Tempest" that could threaten their very existence.

Mostly white men-testifying to "Prospero's Magic" -constructed the discourse of colonial dominance, which often appropriated for itself positive feminine characteristics such as compassion and caring, attributes customarily associated with Victorian notions of proper womanhood. In the process, colonial rhetoric silenced women, whether white or brown, and rendered them as powerless as Prospero's subordinates, Caliban and Ariel. ${ }^{64}$ But Caliban, at least, could revolt against the epistemic violence by "Learning to Curse."65 Swearing in defiance, however, was beyond the imagination of white women in the grand theater of colonialism, where they played both a significant ceremonial role and served as silent, complicit spectators like Miranda, who "gazed with parted lips at the wonders [men] reveal." 66 Although they hardly indulged in the presumed rapture of Miranda's gaze, indigenous women did not easily learn to curse either, except in certain parts of Africa, and colonial administrators often represented them symbolically as the silently suffering victims of barbaric cultures in need of European progress, enlightenment, and technology.

However, the colonizers' vision of women in need of protection-whether their own wives and daughters or indigenous women-often merged with a more ambivalent perception of their other colonial charges, i.e. native men, and colonial officials' language was suffused with symbolic characterizations of both women, whether white or brown, and indigenous men as emotional, irrational, irresponsible, naive, lazy, or self-indulgent. Colonials often depicted indigenous men as capricious and overgrown children, who delighted in nothing but wayang and gambling and were haunted by superstitions and fear of ghosts. At the same time, conforming to the flipside of Victorian sensibilities, they tended to portray both white women and the colonized women they knew most intimately-the nyai, who supposedly "mediated" between the cultures of East and West-as caring only about ephemeral pleasures or not being educated enough to have an interest in any aspect of life beyond the domestic realm. ${ }^{67}$ The idleness and fey qualities of white women

63 de Kat Angelino, Colonial Policy, 2: 648-50.

64 Philip Mason, Prospero's Magic: Some Thoughts on Race and Class (London: Oxford University Press, 1962). See also Philip Mason, Patterns of Dominance (London: Oxford University Press, 1970), and Dominique O. Mannoni, Prospero and Caliban. The Psychology of Colonization, tr. Pamela Powesland (New York: Praeger, 1964).

65 'You taught me language; and my profit on ' $t$

Is, I know how to curse; the red plague rid you

for learning me your language." The Tempest, I,ii.

Quoted in Stephen J. Greenblatt, "Learning to Curse: Aspects of Linguistic Colonialism in the Sixteenth Century," in Learning to Curse. Essays in Early Modern Culture (New York: Routledge, 1990), p. 25. See also: Gayatri Chakravorty Spivak, "Can the Subaltern Speak?," in Marxism and the Interpretation of Culture, ed. Cary Nelson and Lawrence Grossberg (Urbana: University of Illinois Press, 1988), pp. 271-313.

66 Mason, Prospero's Magic, p. 96.

67 Michael Adas, Machines as the Measure of Men. Science, Technology, and Ideologies of Western Dominance (Ithaca: Cornell University Press, 1989), pp. 304-305; for a thoughtful critique of the presumptions about the "mediating" role of the nyai, see Elsbeth Locher-Scholten, "The Nyai in Colonial Deli: A Case of Supposed Mediation," in 
rendered them infantile and helpless in the eyes of colonial men, whereas a Babylonian confusion of tongues typified the communication between Dutch men and indigenous women, whether native housekeepers with whom the Dutch man also shared a bed or anonymous women in the desa. Colonial discourses thus associated femininity with weakness or frivolity and identified non-white peoples with childish helplessness, rendering both naturally dependent on "patriarchal tutelage."68

In sum, Europeans in the colonial theater of the "tropical gothic" resembled dramatists staging an elaborate morality play with a multitude of actors and actresses, who portrayed masters and servants of different skin color, varying levels of eloquence, and distinct styles of elocution. They imposed on the colonized, Asian world the shape of their own culture and European perceptions of gender differences-embodied in what Stephen Greenblatt has called their "kidnapping language" -in order to make that world recognizable, intelligible, habitable, and natural as defined by a Western lexicon. ${ }^{69}$ The legitimation of colonial rule hinged on the description of the "natives" as being unable to speak for themselves, or as not having any language at all.

As a Dutch journalist argued derisively about Indonesians in 1924: "an inlander knows nothing and can not do anything on his own. If he says something, he has heard it from a Dutchman; if he wants something, a Dutchman has guided his desires, and if he produces or creates something a Dutchman stands behind him to nurture and support him. If an inlander were to be a student at a university and he might venture to speak, it would appear that he has no voice of his own and would only parrot what Snouck [Hurgronje] and Hazeu have instructed him to say, so that indigenous students would be nothing but extensions of the voices of Snouck and Hazeu."70 Accordingly, Europeans claimed to have become colonialists in order to teach basic literacy in the cultural grammar of the civilized world to the "natives" and to "assist colonial people to responsibility and higher social standards."71 In the process, they imposed a variety of gendered tropes, symbolically representing either command or subordination, upon indigenous vocabulary. Some native intellectuals, in turn, reacted like "adopted children" and absorbed European culture with a vengeance in order to become evolué and bien élevé, not being content to acquire merely a cursory knowledge of

Indonesian Women and Mediation, ed. Sita van Bemmelen, Madelon Djajadiningrat-Nieuwenhuis, Elsbeth LocherScholten, Elly Touwen-Bouwsma, (Leiden: KITLV Press, 1992).

68 Emily S. Rosenberg, "Gender," in: "A Round Table: Explaining the History of American Foreign Relations," Journal of American History 77, 1 (1990): 119. See also Jan Nederveen Pieterse, Wit over zwart. Beelden van Afrika en zwarten in de westerse populaire cultuur (Amsterdam: Koninklijk Instituut voor de Tropen, 1989), especially Chapter 5, "Kolonialisme en populaire cultuur," pp. 76-101. Nationalist intellectuals in India, too, advocated complex notions of modern womanhood: favoring female education so that Bengali mothers could provide a beneficial "cradle and nursery for the production of future citizens," on the one hand, they caricatured and vilified the educated woman who became independent, assertive, and disruptive of the patriarchal household, on the other. See: Dipesh Chakrabarty, "Womanhood, Home and the Domestic Order: Figures of the Modern in Bengali-Indian Colonial Thought," paper presented at SSRC conference on "Culture, Consciousness, and the Colonial State," Sussex, England, July, 1989; in Subaltem Studies, ed. Ranajit Guha (New Delhi: Oxford University Press, forthcoming).

69 Terence Hawkes, Shakespeare's Talking Animals. Language and Drama in Society (London: Arnold, 1973), p. 212, and Stephen Greenblatt, Marvelous Possessions. The Wonder of the New World (Chicago: University of Chicago Press, 1991), pp. 86-118.

70 Pastoor F. van Lith denouced this attitude in his article about "Het Koloniaal onderwijs-congres" of April 24, 1924, in Djawa 4, 3 (September 1924): 155.

71 Jeffries, Partners for Progress, p. 6. See also Thomas G. August, The Selling of the Empire. British and French Imperialist Propaganda, 1890-1940 (Westport: Greenwood Press, 1985), and Adas, Machines as the Measure of Men, passim. 
Rabelais and Diderot, Shakespeare and Edgar Allen Poe. ${ }^{72}$ As a result, a complete mastery of the language of the colonial "other" enabled sophisticated native intellectuals, such as Tjipto in the Dutch East Indies, to invert or ridicule the gendered depiction of authority and subservience and articulate a colorful and witty anticolonial critique. In North Africa, a few decades later, Algerian nationalists mangled the French appelation bien élevé by converting it into the pejorative beni-wéwé, which came to designate "a class of white man's niggers."73

As long as nationalists used the same cultural idiom as their Dutch colonial "lords," however, the latter continued to address Indonesian intellectuals as "bondsmen" who presumably not only understood but, above all, complied with the disciplinary language of their European masters. ${ }^{74}$ Only a subtle refusal by nationalists to participate in the speech of the colonial rulers managed to rattle the self confidence of the Indies state and to sabotage Dutch authority in the Indonesian archipelago. In the end, it was primarily the development of a vernacular counter discourse, which concocted a new political vocabulary with words such as merdeka, bebas, or frij, that enabled Indonesian nationalists to hurl lethal stones at the "Glass House" of Dutch colonial dominance. 75 In other words, once they "learned to curse," by using words other than Dutch ones or by appropriating familiar words and endowing them with a new ideological meaning, nationalists could challenge colonial rule. Thus, when the Dutch nation in 1913 celebrated its liberation and independence from Napoleonic oppression a hundred years before, Soewardi Soerjaningrat (Ki Hadjar Dewantoro) seized the occasion to excoriate the hypocrisy of the Dutch for withholding the very same merdeka from Indonesians; in the process, Soewardi exposed the contradictions between Dutch nationalist pride, on the one hand, and imperialist exploitation, on the other. ${ }^{76}$

Maledictions of this nature, represented semantically in such a way that they garbled Dutch cultural idiom, were capable of transmitting novel political meanings and eliciting emotional responses. From a visceral and frightened Dutch perspective, the rallying cry merdeka emerged as nothing but a swear word that mobilized public sentiment on a large scale and aroused the residual irrationality of Indonesians by making them run amuk.

The youthful and ingenious colloquial speech of Indonesian nationalism also subverted European masculine and feminine metaphors which signify either power or weakness. Bahasa Indonesia, after all, is mostly a gender-neutral language, making it cumbersome, to

\footnotetext{
72 Fanon, The Wretched of the Earth, pp. 218-19.

73 Edward W. Said, "Representing the Colonized. Anthropology's Interlocutors," Critical Inquiry 15, 2 (Winter 1989): 210.

74 Theodore Friend employs this Hegelian dichotomy in "Lordship and Bondage: The Philippines, Indonesia, and Japanese Impact, 1942-1945." Occasional Paper No. 19, Woodrow Wilson International Center for Scholars, Washington DC. See also idem, The Blue-Eyed Enemy. Japan against the West in Java and Luzon, 1942-1945 (Princeton: Princeton University Press, 1988).

75 The term "House of Glass" is associated with Pramoedya Ananta Toer. See: Rumah kaca (Jakarta: Hasta Mitra, 1988), or Max Lane, tr., House of Glass (Sidney: Australia Penguin Books, 1992). However, J.C. Baud, the Dutch minister of colonies between 1840 and 1848, used the phrase as early as 1847 when he noted that "colonial administration was ... in a glass house, visible on all sides." See Cornelis Fasseur, The Politics of Colonial Exploitation. Java, the Dutch, and the Cultivation System, tr. R. E. Elston and Ary Kraal (Ithaca: Cornell Southeast Asia Program, 1992), p. 15.

76 The festivities had been planned for November 30, 1913. In De Expres, Soewardi Soerjaningrat (Ki Hadjar Dewantoro) wrote: "if temporarily I were to be a Dutchman, I would be ashamed to celebrate the independence of my country in these colonized lands ... because if I were a Dutchman I would wish these [colonized] lands to share in my happiness and thus use this occasion to return their independence to them. ..." See Margono Djojohadikusumo, Herinneringen, pp. 52-53, and Benedict Anderson, Imagined Communities. Reflections on the Origins and Spread of Nationalism (London: Verso, 1983), pp. 107-8.
} 
say the least, to formulate elusive figures of speech that associate authority with masculinity or conflate feebleness with femininity. Not that the modern Indonesian Republic has granted women august positions of formal power in the political hierarchy, even if Bu Tien's indomitable "Ibuism" has provided a feminine variation on the theme of Suharto's "Bapakism" since the late 1960s. One could argue, in fact, that the Suharto regime in its twilight years has done all it could to reinforce patriarchal stereotypes by circumscribing women's social and political roles more rigidly along gender-specific lines. For example, the panoply of women's organizations and women's self-help cooperatives that are officially sanctioned by the "New Order," such as Dharma Wanita, tend to reinforce the traditional roles of women as derivative and subservient to their husbands' interests. ${ }^{77}$ The development of the Indonesian language, too, has been stultified by dry and tedious bureaucratic speech-language irrevocably divorced from the realm of human passions, whether trivial or sublime. As Goenawan Mohamad has lamented very recently: "Our language has been ripped from the world, stripped of shape, smell, color and form, cleansed of the grit and grafiti, the rumpus and commotion, that make up real life."78 However, during the excitement and fervor of the anticolonial struggle after 1945, when life and death were very real, the invented cultural grammar of the self-proclaimed independent nation did try to leave behind the gendered discourses of European colonialism in order to construct a novel political language that no longer unwittingly reinforced the stereotypes of women as inherently subordinate and compliant.

77 Laura Cooley, "Maintaining Rukun for Javanese Households and for the State," in Women and Mediation, pp. 229-47.

78 Goenawan Mohamad, "Pasemon. On Allusion and Illusions," Acceptance speech delivered at the award ceremony of the 1992 Professor Teeuw Award, University of Leiden, May 25, 1992. 